\title{
Effects of simvastatin and cholestyramine on bile lipid composition and gall bladder motility in patients with hypercholesterolaemia
}

\author{
J W A Smit, K J Van Erpecum, P Portincasa, W Renooij, D W Erkelens, \\ G P Van Berge-Henegouwen
}

\begin{abstract}
Although the effects of 3-hydroxy, 3methylglutaryl coenzyme A (HMG-CoA) reductase inhibitors and bile acid sequestrants on bile lipid composition have been studied separately, no data are available on combination therapy of these drugs. Moreover, the effects of prolonged (four weeks) administration of these drugs on gall bladder motility, an important determinant of cholesterol gall stone formation, have not been studied so far. A prospective study was therefore performed with eight patients who had hypercholesterolaemia (age 53 (5) (SEM), body mass index $27 \cdot 4(1 \cdot 1) \mathrm{kg} \mathrm{m}^{-2}$, low

differ $(5.7(0.9) \mathrm{ml}$ (simvastatin) $v 5.9(0 \cdot 7)$ (baseline). During cholestyramine and combined treatment, no significant differences in gall bladder motility were seen. In conclusion, this study suggests that HMGCoA reductase inhibitors alone and combined with cholestyramine do not affect major determinants of cholesterol gall stone formation, for example, CSI and gall bladder emptying. In addition cholestyramine alone and combined with simvastatin leads to a strong decrease of bile salt hydrophobicity, which may be beneficial in the prevention of nucleation of cholesterol crystals.

(Gut 1995; 37: 654-659)
\end{abstract} density lipoprotein cholesterol $5.9(0.3)$ mmol/1). They received treatment during three periods of four weeks with simvastatin $20 \mathrm{mg} /$ day, cholestyramine $4 \mathrm{~g}$ twice daily, and a combination of both in random order, each treatment period separated by a two week wash out period. Before treatment and after each treatment period, postprandial gall bladder motility was studied with ultrasound, followed by duodenal bile sampling. Serum cholesterol decreased in all subjects in any treatment period illustrating good compliance. Molar percentages in duodenal bile of cholesterol, phospholipids, and bile salts were unchanged during simvastatin and cholestyramine treatment. During combined therapy percentage bile salts was lower $(72 \cdot 5(2.9) \% v$ $77.8(1 \cdot 7) \%$ at baseline, $\mathrm{p}<0.05)$ whereas phospholipids were higher $(21.2(2.4) \% v$ $16.4(1.3) \%$ at baseline, $p<0.05)$. As a result cholesterol saturation index (CSI) did not change in any treatment period. No cholesterol crystals were detected in any bile sample, taken at baseline and after each treatment period. Bile salt hydrophobicity index during cholestyramine $(0.19(0.02))$ and combined treatment $(0.22(0.01))$ decreased strongly compared with baseline $(0.34(0.01)$, $\mathbf{p}<0.001, \mathbf{p}<0.01$, respectively), resulting from increased proportions of glycocholate (59.4 (3.9)\% (cholestyramine), $55 \cdot 6(2 \cdot 4) \%$ (combination), and $28 \cdot 2(2 \cdot 2)$ (baseline), $\mathbf{p}<0.001)$ ) and decreased proportions of deoxycholic acid and chenodeoxycholic acid. Fasting gall bladder volume was increased during simvastatin $(28.7(2.8) \mathrm{ml}) v$ baseline $(23.2(2.3) \mathrm{ml}$, $\mathbf{p}<0.01)$ whereas, residual volume did not
Keywords: simvastatin, cholestyramine, bile, lipids, gall bladder, motility.

Inhibitors of 3-hydroxy, 3-methylglutaryl coenzyme A (HMG-CoA) reductase, are now widely used for treatment of hypercholesterolaemia. They reduce the cellular pool of cholesterol, thereby enhancing the synthesis of receptors for low density lipoprotein cholesterol, which leads to decreased values of low density lipoprotein cholesterol. ${ }^{1-4}$ In severe hypercholesterolaemia, HMG-CoA reductase inhibitors are commonly combined with bile acid sequestrants such as cholestyramine, which has an additional cholesterol lowering effect. $^{5-8}$ Interest has grown in the effects of HMG-CoA reductase inhibitors on biliary lipid composition, a determinant of cholesterol gall stone formation. Other hypolipidaemic drugs like clofibrate or gemfibrozil increase cholesterol secretion into bile thus giving rise to an increased biliary cholesterol saturation index (CSI) and an increased risk of gall stones. ${ }^{9-11}$ In a number of studies on the effects of $\mathrm{HMG}-\mathrm{CoA}$ reductase inhibitors on bile composition, generally performed in hypercholesterolaemic patients, CSI of duodenal bile was found to be reduced. ${ }^{12} 13$ Although controversial, ${ }^{14}$ a role for $\mathrm{HMG}-\mathrm{CoA}$ reductase inhibitors in the dissolution therapy of cholesterol gall stones has been suggested. ${ }^{15}$ In contrast with HMG-CoA reductase inhibitors, cholestyramine treatment is not known to influence CSI. ${ }^{16} !^{17}$ No data are available on the effects of combined treatment with HMGCoA reductase inhibitors and cholestyramine on bile lipid composition.

Apart from bile lipid composition, impaired gall bladder motility plays an important part in 
the pathogenesis of cholesterol gall stone disease, providing the time necessary for the precipitation of cholesterol crystals from supersaturated bile and for their subsequent aggregation and growth to stones. ${ }^{18}{ }^{19}$ No studies on the effects of HMG-CoA reductase inhibitors on gall bladder motility have been performed so far. Although a short-term dose of cholestyramine has been described to enhance gall bladder emptying, ${ }^{20}$ no data on longterm treatment with this drug on gall bladder motility are available. As bile lipid composition and gall bladder motility are important determinants in cholesterol gall stone formation, we performed a prospective study in eight subjects with primary hypercholesterolaemia, investigating the effects of four weeks' treatment with simvastatin and cholestyramine, alone and in combination on biliary lipid composition, presence of cholesterol crystals in fresh bile as parameter for lithogenicity, and gall bladder motility.

\section{Methods}

Patients

Eight patients (four females, four males; age 53 (5) years (mean (SEM); body mass index $27 \cdot 4$ $(1 \cdot 1) \mathrm{kg} \mathrm{m}^{-2}$, per cent ideal body weight 120 (4\%)) with recently diagnosed primary hypercholesterolaemia (low density lipoprotein cholesterol $\geqslant 4.14$ with standard lipid lowering diet, triglycerides $<2.6 \mathrm{mmol} / \mathrm{l}$ ) were recruited from the outpatient clinic of the University Hospital Utrecht, the Netherlands. Apart from hypercholesterolaemia, the participants had to be healthy, according to a medical questionnaire, physical examination, and routine laboratory screening including liver biochemistry and creatine kinase values. They had no previous operations of the gastrointestinal tract. All had a normal gall bladder and common bile duct at ultrasonography. No potentially interfering treatment was allowed.

\section{Protocol}

The participants received treatment during three subsequent periods of four weeks with each of the following treatment regimens; $20 \mathrm{mg}$ simvastatin/day alone taken at bedtime (Zocor, Merck Sharp and Dohme, Haarlem, the Netherlands), cholestyramine $4 \mathrm{~g}$ twice daily, taken at breakfast and dinner (Questran, Bristol Myers Squibb, Woerden, the Netherlands) alone, or a combination of both treatment regimens. The sequence of treatment regimens was assigned randomly. The treatment periods were separated by a two week wash out period. Patients were carefully instructed to have an interval of at least four hours between cholestyramine and simvastatin during the combined treatment period. ${ }^{21} \mathrm{At}$ baseline, and at the end of each treatment period, fasting blood samples and duodenal bile were collected and gall bladder motility was studied. These procedures were performed at $800 \mathrm{am}$, in the fasting state, the last dose taken the evening before. The duodenal sampling was always performed after the motility study, to avoid any potential influence of bile salt depletion resulting from biliary drainage on gall bladder motility. Patients were asked to adhere to their lipid lowering diet throughout the study. Compliance was checked by a tablet count at the end of each treatment period.

Approval for the protocol was obtained from the ethical committee of the University Hospital Utrecht. All patients gave written informed consent.

\section{Duodenal bile collection}

Duodenal bile sampling was performed after an overnight fast at $800 \mathrm{am}$. After duodenal intubation, bile was sampled after induction of gall bladder contraction by slow intravenous administration of ceruletide (Takus, Farmiltalia, Milan, Italy). Three $\mathrm{ml}$ of the most concentrated bile was preserved. Two $\mathrm{ml}$ of gall bladder bile was mixed immediately with $6 \mathrm{ml}$ chloroform/methanol $(2 / 1 \mathrm{vol})$ in ice chilled tubes, extracted according to Bligh and Dyer, ${ }^{22}$ and stored at $-20^{\circ} \mathrm{C}$ until further analysis. From the remainder of the bile, $5 \mu 1$ was analysed microscopically for cholesterol monohydrate crystals, the rest was stored immediately at $-20^{\circ} \mathrm{C}$ until further analysis for total bile salt concentration and bile salt composition.

\section{Bile lipid composition}

In the bile extract, cholesterol and phospholipid were measured colorimetrically (Monotest, Boehringer Mannheim, Germany and SopaChem Phospholipids, Sopar Biochem, Brussels, Belgium, respectively). Total bile salt concentration was measured in whole bile using $3 \alpha$-hydroxysteroid dehydrogenase according to Turley. $^{23}$ The CSI was determined using Carey's critical tables assuming a total lipid concentration of $10 \mathrm{~g} / \mathrm{dl} .^{24}$ Conjugated bile salt species were analysed in whole bile by isocratic high performance liquid chromatography on a Waters Bondapak C-18 10 $\mu \mathrm{m}$ column (using methanol/phosphate buffer as solvent, $\mathrm{pH} 5 \cdot 2$, flow rate $1 \mathrm{ml} / \mathrm{min}$ ) and detection at $200 \mathrm{~nm} .{ }^{25}$ Cumulative bile salt hydrophobicity index was calculated according to Heuman. ${ }^{26}$

\section{Gall bladder motility}

After an overnight fast, gall bladder volume was measured by real time ultrasonography (Pie Medical 250, Maastricht, the Netherlands: $5 \cdot 0 \mathrm{MHz}$ transducer) at $800 \mathrm{am}$. Sagittal and transverse scans of the gall bladder at its largest dimensions were obtained. Subsequently, after consumption of a test meal, gall bladder images were made at regular intervals during two hours. The ultrasound equipment contained software for calculation of gall bladder volume according to the sum of cylinders method. ${ }^{27} 28$ The test meal consisted of one slice of bread, $5 \mathrm{~g}$ margarine, $50 \mathrm{~g}$ cheese, one boiled egg, $200 \mathrm{ml}$ yogurt, and 
$50 \mathrm{~g}$ glucose. This equals $30 \mathrm{~g}$ fat, $30 \mathrm{~g}$ protein, and $70 \mathrm{~g}$ carbohydrate and gives a physiological stimulation of gall bladder emptying. As characteristics of gall bladder motility, fasting volume (mean of measurements at 15 and 0 minutes before test meal; $\mathrm{V}_{0}$ in $\mathrm{ml}$ ), and residual postprandial volume $\left(\mathrm{V}_{\min }\right.$ in $\left.\mathrm{ml}\right)$ were measured. As parameters for postprandial gall bladder emptying, maximal decrement of gall bladder volume in $\mathrm{ml}$ and percentage $\left(\Delta \mathrm{V}_{\max } \mathrm{ml}\right.$ and $\left.\Delta \mathrm{V}_{\max } \%\right)$ were calculated.

\section{Serum lipid analysis and laboratory safety parameters}

Serum lipid concentrations were measured at baseline and after four weeks of each treatment period in blood samples taken after 12 hours of overnight fasting. Total cholesterol and triglycerides were determined by enzymatic colorimetric methods (Boehringer Mannheim CHOD-PAP and GPO-PAP). High density lipoprotein cholesterol was determined in the supernatant after precipitation of low density lipoprotein and very low density lipoprotein cholesterol. Low density lipoprotein cholesterol was calculated using the Friedewald formula. ${ }^{29}$ Laboratory safety parameters were determined by standard methods.

\section{Statistical analyses}

Results are shown as mean (SEM) unless stated otherwise. Serum lipids, gall bladder motility parameters, and bile lipid parameters at baseline and at the end of each treatment period were evaluated by repeated measures of one way analysis of variance. When a statistically significant difference was detected, results were further analysed by Fisher's LSD test. A two tailed probability of less than 0.05 is considered significant. ${ }^{30}$

\section{Results}

\section{Patients}

One patient could not endure the cholestyramine treatment during the second treatment period and left the study after completing the first (simvastatin) treatment period. Baseline parameters and results after simvastatin treatment for this patient were included in the analysis. The other patients completed the study. No adverse events were seen.

\section{Serum lipid parameters}

Table I gives the serum lipid concentrations. All treatment regimens induced decreases in

TABLE I Serum lipid concentrations in eight patients with primary hypercholesterolaemia, treated for four weeks with simvastatin and cholestyramine, alone or in combination

\begin{tabular}{lllll}
\hline & Baseline & $\begin{array}{l}\text { Simvastatin } \\
(20 \mathrm{mg} / \text { day })\end{array}$ & $\begin{array}{l}\text { Cholestyramine } \\
(8 \mathrm{~g} / \text { day })\end{array}$ & Combination \\
\hline Total-cholesterol $(\mathrm{mmol} / \mathrm{l})$ & $8 \cdot 1(0 \cdot 2)$ & $5 \cdot 7(0 \cdot 3)^{\star}$ & $7 \cdot 4(0.2) \dagger$ & $5 \cdot 5(0 \cdot 2)^{\star}$ \\
HDL-cholesterol $(\mathrm{mmol} / \mathrm{l})$ & $1 \cdot 3(0 \cdot 1)$ & $1 \cdot 5(0 \cdot 1) \dagger$ & $1 \cdot 5(0 \cdot 1) \dagger$ & $1 \cdot 5(0 \cdot 1) \dagger$ \\
LDL-cholesterol $(\mathrm{mmol} / \mathrm{l})$ & $5 \cdot 9(0 \cdot 3)$ & $3 \cdot 1(0 \cdot 3)^{\star}$ & $4 \cdot 4(0.3)^{\star}$ & $2 \cdot 9(0 \cdot 1)^{\star}$ \\
Triglycerides $(\mathrm{mmol} / \mathrm{l})$ & $2 \cdot 1(0 \cdot 3)$ & $2 \cdot 5(0 \cdot 8)$ & $3 \cdot 3(0 \cdot 7) \dagger$ & $2 \cdot 3(0 \cdot 6)$ \\
\hline
\end{tabular}

${ }^{\star} \mathrm{p}<0.01 v$ baseline; $\mathrm{tp}<0.05 v$ baseline. Data shown as mean (SEM). low density lipoprotein cholesterol in all patients confirming good patient compliance. High density lipoprotein cholesterol rose significantly in all treatment periods, whereas triglycerides increased during cholestyramine treatment.

\section{Bile lipid analysis}

As Table II shows, molar percentages of biliary cholesterol, phospholipid, and bile salts were not different from baseline at the end of the simvastatin and cholestyramine treatment periods, whereas after combined treatment, bile salts were decreased significantly compared with baseline, whereas phospholipids were increased significantly. As a result, CSI did not differ between any treatment regimen and baseline.

Biliary bile salt composition (Table III) differed from baseline in the cholestyramine and combined treatment periods: percentage of glycocholate was increased strongly in both treatment periods compared with baseline whereas both taurine and glycine conjugates of deoxycholic acid and chenodeoxycholic acid were decreased. As a consequence, hydrophobicity index was decreased strongly after treatment with cholestyramine alone or in combination with simvastatin. Simvastatin alone had no influence on bile salt composition. The ratio of taurine/glycine conjugated bile salts decreased strongly during cholestyramine monotherapy and combined treatment. As taurine and glycine conjugates of lithocholic acid together constituted $<1 \%$ of total bile acids at baseline and during all treatment regimens, these data were omitted in Table III.

\section{Cholesterol crystals in fresh bile}

No cholesterol crystals were present in any bile sample, taken at baseline and after each treatment period.

\section{Gall bladder motility}

Table IV shows parameters of gall bladder contraction and the Figure shows gall bladder contraction curves. Fasting gall bladder volume increased in seven of eight patients during simvastatin monotherapy, compared with baseline volume $(28 \cdot 7(2 \cdot 8), 23 \cdot 2(2 \cdot 3) \mathrm{ml}$ respectively, $\mathrm{p}<0.01)$. Despite this increase, minimal postprandial volume $\left(\mathrm{V}_{\min } 5.7(0.9)\right.$, $5.9(0.7) \mathrm{ml}$ respectively) did not change. Therefore, both absolute and relative gall bladder emptying $\left(\Delta \mathrm{V}_{\max } \mathrm{ml}\right.$ and $\left.\Delta \mathrm{V}_{\max } \%\right)$ increased significantly during simvastatin monotherapy. During cholestyramine monotherapy and combined therapy, no significant differences in fasting gall bladder volumes, minimal prostprandial volume, and gall bladder emptying were seen.

\section{Discussion}

This study was performed to assess the effects of simvastatin and cholestyramine, alone and in combination on biliary lipid composition 
TABLE II Biliary lipid composition in eight patients with primary hypercholesterolaemia, treated for four weeks with simvastatin and cholestyramine, alone or in combination

\begin{tabular}{|c|c|c|c|c|}
\hline & Baseline & $\begin{array}{l}\text { Simvastatin } \\
(20 \mathrm{mg} / \text { day })\end{array}$ & $\begin{array}{l}\text { Cholestyramine } \\
\text { (8 g/day) }\end{array}$ & Combination \\
\hline $\begin{array}{l}\text { CSI } \\
\text { Molar percentages }\end{array}$ & $0.99(0.08)$ & $1.00(0.08)$ & $1.03(0.15)$ & $0.93(0.14)$ \\
\hline $\begin{array}{l}\text { Cholesterol } \\
\text { Phospholipids } \\
\text { Bile salts }\end{array}$ & $\begin{array}{r}5 \cdot 8(0 \cdot 6) \\
16 \cdot 4(1 \cdot 3) \\
77 \cdot 8(1 \cdot 7)\end{array}$ & $\begin{array}{r}6 \cdot 0(0.6) \\
16 \cdot 6(0.9) \\
77 \cdot 4(1 \cdot 4)\end{array}$ & $\begin{array}{r}5 \cdot 8(0.8) \\
15 \cdot 7(1 \cdot 2) \\
78 \cdot 5(1 \cdot 4)\end{array}$ & $\begin{array}{c}6 \cdot 3(1 \cdot 1) \\
21 \cdot 2(2 \cdot 4)^{\star} \\
72 \cdot 5(2 \cdot 9)^{\star}\end{array}$ \\
\hline
\end{tabular}

${ }^{\star} \mathrm{p}<0.05 v$ baseline. Data shown as mean (SEM).

TABLE III Bile salt composition in eight patients with primary hypercholesterolaemia, treated for four weeks with simvastatin and cholestyramine, alone or in combination

\begin{tabular}{|c|c|c|c|c|}
\hline & Baseline & $\begin{array}{l}\text { Simvastatin } \\
(20 \mathrm{mg} / \text { day })\end{array}$ & $\begin{array}{l}\text { Cholestyramine } \\
(8 \mathrm{~g} / \text { day })\end{array}$ & Combination \\
\hline \multirow{11}{*}{$\begin{array}{l}\text { Tauroursodeoxycholate (\%) } \\
\text { Glycoursodeoxycholate } \\
\text { Taurocholate } \\
\text { Glycocholate } \\
\text { Taurochenodeoxycholate } \\
\text { Taurodeoxycholate } \\
\text { Glycochenodeoxycholate } \\
\text { Glycodeoxycholate } \\
\text { Hydrophobicity index } ₫ \\
\text { Taurine/glycine conjugated } \\
\text { bile salts }\end{array}$} & $0.49(0.16)$ & $0 \cdot 50(0 \cdot 16)$ & $0.08(0.03)$ & $0 \cdot 10(0.05)$ \\
\hline & $1.91(0.58)$ & $2.06(0.50)$ & $0.65(0.24)$ & $0.56(0.25)$ \\
\hline & $9.67(0.96)$ & $10.40(0.91)$ & $10 \cdot 07(1 \cdot 16)$ & $10 \cdot 47(2 \cdot 14)$ \\
\hline & $28 \cdot 23(2 \cdot 23)$ & $27.64(1.88)$ & $59.37(3.93)^{\star}$ & $55.55(2.43)^{\star}$ \\
\hline & $9.16(1.06)$ & $9.90(1.14)$ & $2.77(0.79) \dagger$ & $3.52(0.46)^{\star}$ \\
\hline & $4.69(1.05)$ & $5.13(0.89)$ & $0.88(0.33) \ddagger$ & $1.50(0.26) \ddagger$ \\
\hline & $27 \cdot 41(2 \cdot 2)$ & $26.17(2.58)$ & $19.33(1.89) \dagger$ & $19.37(1.34) \dagger$ \\
\hline & $18 \cdot 44(2.73)$ & $18.20(2.48)$ & $6.85(1.89) \dagger$ & $8.93(1.68) \ddagger$ \\
\hline & $0.34(0.01)$ & $0.33(0.01)$ & $0.19(0.02)^{\star}$ & $0.22(0.01)^{\star}$ \\
\hline & $0.23(0005)$ & $0.26(0,05)$ & 0.9001 & 0.10 \\
\hline & $0.33(0.05)$ & $0.36(0.05)$ & $0.16(0.04) \dagger$ & $0.19(0.04) \dagger$ \\
\hline
\end{tabular}

${ }^{\star} \mathrm{p}<0.001 v$ baseline; $\nmid \mathrm{p}<0.01 v$ baseline; $\neq \mathrm{p}<0.05 v$ baseline; osee text.

Data shown as mean (SEM).

TABLE IV Postprandial gall bladder motility in eight patients with primary

hypercholesterolaemia, treated for four weeks with simvastatin and cholestyramine, alone or in combination

\begin{tabular}{lllll}
\hline & Baseline & $\begin{array}{l}\text { Simvastatin } \\
(20 \mathrm{mg} / \text { day })\end{array}$ & $\begin{array}{l}\text { Cholestyramine } \\
(8 \mathrm{~g} / \text { day })\end{array}$ & Combination \\
\hline Fasting volume $\left(\mathrm{V}_{0}\right)(\mathrm{ml})$ & $23 \cdot 2(2 \cdot 3)$ & $28 \cdot 7(2 \cdot 8)^{\star}$ & $23 \cdot 4(4 \cdot 2)$ & $26 \cdot 0(4 \cdot 9)$ \\
Minimal volume $\left(\mathrm{V}_{\min }\right)(\mathrm{ml})$ & $5 \cdot 9(0 \cdot 7)$ & $5 \cdot 7(0 \cdot 9)$ & $8 \cdot 9(2 \cdot 4)$ & $9 \cdot 5(2 \cdot 3)$ \\
Maximal decrease $(\%)$ & $73(3)$ & $81(2) \dagger$ & $66(3)$ & $65(4)$ \\
Maximal decrease $(\mathrm{ml})$ & $17 \cdot 3(2 \cdot 2)$ & $23 \cdot 0(2 \cdot 3)^{\star}$ & $14 \cdot 5(1 \cdot 9)$ & $16 \cdot 6(2 \cdot 9)$ \\
\hline
\end{tabular}

${ }^{\star} \mathrm{p}<0.01 v$ baseline; $\mathrm{fp}<0.05 v$ baseline. Data shown as mean (SEM).

and gall bladder motility. The CSI of duodenal bile did not differ from baseline in any of the treatment periods. Although the unchanged CSI under simvastatin treatment may be unexpected at first sight unchanged CSI under treatment with HMG-CoA reductase inhibitors was reported in other studies. ${ }^{31-34}$

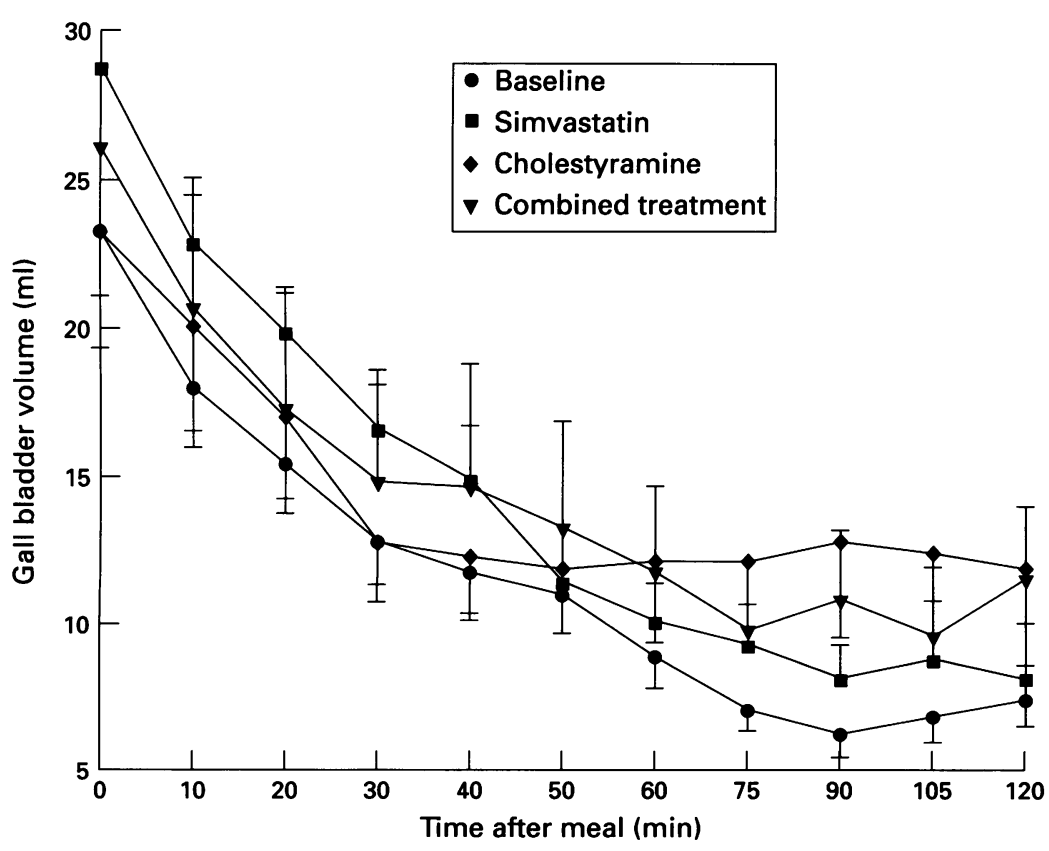

Effects of four weeks' treatment with simvastatin, cholestyramine, alone or in combination on postprandial gall bladder emptying in hypercholesterolaemic patients.
The unchanged CSI under simvastatin in this study is probably not the result of type II error, as CSI decreased in only one patient. The absence of an effect on CSI of cholestyramine monotherapy is in agreement with earlier studies. ${ }^{1617}$ Under combined treatment with simvastatin and cholestyramine, a decreased percentage of bile salts in duodenal bile was seen. In the case of interruption of the enterohepatic circulation, as under treatment with bile salt sequestrants, maintenance total bile salt pool size depends on de novo bile salt synthesis, ${ }^{17} 35-37$ which is reflected by enhanced activity of $7 \alpha$ hydroxylase (the rate limiting enzyme in bile salt synthesis) in this situation. ${ }^{161737}$ HMG-CoA reductase inhibitors have been shown in vitro to reduce the activity of $7 \alpha$ hydroxylase caused by decreased substrate for this enzyme. ${ }^{38}$ Therefore bile salt synthesis and secretion may be susceptible for HMGCoA reductase inhibitors in the case of interrupted enterohepatic circulation. Indeed, in patients with bile fistula, decreased bile salt secretion was seen. ${ }^{39} 40$ Therefore, increased susceptibility of bile salt synthesis for HMGCoA reductase inhibitors during treatment with cholestyramine may explain the effects on bile salts as found in this study. Despite this decrease in molar percentage of bile salts, CSI under combination therapy was unchanged because of the increased molar percentage of phospholipids. The absence of effects on CSI in any of the treatment regimens is in agreement with the finding that no cholesterol crystals were seen in the bile samples during any treatment.

Simvastatin monotherapy did not affect bile salt pool composition, whereas profound changes in bile salt composition were found under treatment with cholestyramine alone and in combination with simvastatin. In both groups percentage of glycocholic acid was increased substantially, whereas both tauro and glyco conjugates of chenodeoxy and deoxycholic acid were decreased, resulting in an important reduction of bile salt hydrophobicity index. These findings obviously relate to the preferential binding by cholestyramine of hydrophobic bile salts (deoxycholic acid and chenodeoxycholic acid) as reported in earlier studies $^{16173741}$ and to the preferential neosynthesis of cholic acid over chenodeoxycholic acid by the liver in the case of interrupted enterohepatic circulation. ${ }^{42}$ To our knowledge the effects of combination therapy on bile salt composition have not been studied previously. The changes in bile salt composition as seen in this study may be beneficial as hydrophilic bile salts have weaker detergent capacity than more hydrophobic bile salts and as a result may induce less nucleation of cholesterol crystals from biliary vesicles. ${ }^{43}$ Moreover, cholesterol absorption from the gut may be decreased during cholestyramine treatment ${ }^{37}$ probably related to decreased micellar formation by less hydrophobic bile salts. The increased ratio of glycine/taurine conjugated bile salts may result from loss of taurine in the case of interrupted enterohepatic circulation. ${ }^{44}$

Under simvastatin and combination treatment, fasting gall bladder volume was 
increased compared with baseline, without affecting contractility. The increased fasting gall bladder volume cannot be explained by biliary lipid composition. Also a relation with serum cholesterol concentrations seems unlikely. An explanation could be that simvastatin increases bile salt independent of bile flow by an osmotic effect because after being metabolised it is excreted into the bile for approximately $90 \% .{ }^{45} 46$ The absence of effects with four weeks of treatment with cholestyramine on fasting gall bladder volume is in agreement with findings from our group in seven healthy volunteers, treated with $8 \mathrm{~g}$ cholestyramine/day. After an initial decrease, fasting gall bladder volume was restored to its pretreatment value after seven days of cholestyramine administration (unpublished data). Apparently, the interference with the negative feedback control of intraduodenal bile salts on cholecystokinin release, which is the proposed mechanism of gall bladder contraction during short-term administration of cholestyramine, ${ }^{47}$ does not occur during prolonged treatment.

In conclusion, this study suggests that HMG-CoA reductase inhibitors alone and combined with cholestyramine do not affect major determinants of cholesterol gall stone formation, for examples, biliary cholesterol saturation and gall bladder emptying. In addition cholestyramine alone and combined with simvastatin leads to a strong decrease of bile salt hydrophobicity, which is considered beneficial for the prevention of nucleation of cholesterol crystals in gall bladder bile.

These data suggest that simvastatin and cholestyramine alone or in combination do not increase the risk of cholesterol gall stone formation.

Dr van Erpecum is a fellow of the Royal Netherlands Academy of Arts and Sciences.

1 Angelin B. Regulation of hepatic cholesterol metabolism in man. Ann Med 1991; 23: 177-80.

2 Grundy SM. HMG-CoA reductase inhibitors for treatment of hypercholesterolaemia. $N$ Engl $\mathcal{J}$ Med 1988; 319: of hyp 24 .

3 Maher VM, Thompson GR. HMG CoA reductase inhibitors as lipid lowering agents: five years experience with lovastatin and appraisal of simvastatin and pravastatin. $Q \mathcal{f}$ Med 1990; 74: 165-75.

4 Ditschuneit $\mathrm{HH}$, Kuhn K, Ditschuneit $\mathrm{H}$. Comparison of different HMG-CoA reductase inhibitors. Eur $\mathfrak{f}$ Clin Pharmacol 1991; 40 (suppl 1): 27-32.

5 Mabuchi H, Sakai T, Sakai Y, Yoshimura A, Watanabe A, Wakasugi $\mathrm{T}$, et al. Reduction of serum cholesterol in heterozygous patients with familial hypercholesterolaemia. Additive effects of compactin and cholestyramine. NEngl f Med 1983; 398: 609-13.

6 Illingworth DR, Bacon S. Treatment of heterozygous familial hypercholesterolaemia with lipid lowering drugs. Arteriosclerosis 19899 (suppl I): 121-34.

7 Vega GL, East CA, Grundy SM. Effects of combined therapy with lovastatin and colestipol in heterozygous familial hypercholesterolaemia. Effects on kinetics of apolipoprotein B. Arteriosclerosis 19899 (suppl I): 135-44.

8 Kostis JB, Wilson AC, Tannenbaum AK, Pan HY, Kuo PY. Long term combination therapy of primary hypercholes-
terolaemia with pravastatin and cholestyramine. Circulation 1989; 80: 128.

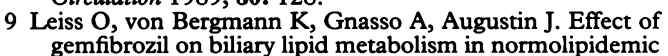
subjects. Metabolism 1985; 34: 74-82.

10 Pertsemlidis D, Panveliwaila D, Ahrens EH Jr. Effects of clofibrate and an estrogen-progestin combination on fasting biliary lipids and cholic acid kinetics in man. Gastroenterology 1974; 66: 565-73.

11 The Coronary Drug Project Research Group. Coronary Drug Project. Clofibrate and niacin in coronary heart Drug Project. Clofibrate and niacin
disease. $f A M A$ 1975; 231: 360-81.

12 Duane WC, Hunninghake DB, Freeman ML, Pooler PA, Schlasner L, Gebhard RL. Simvastatin, a competitive inhibitor of HMG-CoA reductase lowers cholesterol saturation index of gallbladder bile. Hepatology 1988; 8: $1147-50$.

13 Hoogerbrugge-vd Linden N, de Rooy FWM, Jansen H, van Blankenstein $M$. Effect of pravastatin on bilary lipid composition and bile synthesis in familial hypercholesteroposition and but 1990; 31: 348-50.

14 Bazzoli F, Mazella G, Zagari RM, Orsini M, Polimeni C, Novelli $\mathrm{V}$, et al. HMG-CoA reductase inhibitors lower Novelli $\mathrm{V}$, et al. HMG-CoA reductase inhibitors lower
biliary cholesterol saturation but are ineffective cholesbiliary cholesterol saturation but are ineffective choles-
terol gallstone dissolving agents. Gastroenterology 1992; 102: A302.

15 Smit JWA, van Erpecum KJ, Stolk MFJ, Geerdink RA, Cluysenaer OJJ, Erkelens DW, et al. Successful dissolution of cholesterol gallstone during treatment with pravastatin. Gastroenterology 1992; 103: 1068-70.

16 Reihner E, Angelin B, Rudling M, Ewerth S, Björkhem I, Einarsson K. Regulation of hepatic cholesterol metabolism in humans: stimulatory effects of cholestyramine on HMG-CoA reductase activity and low density lipoprotein receptor expression in gallstone patients. $\mathcal{F}$ Lipid Res 1990; 31: 2219-26.

17 Reihner E, Bjorkhem I, Angelin B, Ewerth S, Einarsson K. Bile acid synthesis in humans: regulation of hepatic microsomal cholesterol $7 \alpha$-hydroxylase activity. Gastroenterology 1989; 97: 1498-505.

18 Van Erpecum KJ, VanBerge-Henegouwen GP, Stolk MFJ, Hopman JPM, Jansen JBMJ, Lamers CBHW. Fasting gallbladder volume, postprandial emptying and chlolecystokinin release in gallstone patients and normal subjects. f Hepatol 1992; 14: 194-202.

19 Portincasa P, Di Ciaula A, Baldassarra G, Palmieri V, Gentile A, Cimmono A, et al. Gallbladder motor function in gallstone patients. Somographic and 'in vitro' studies on the role of gallstones, smooth muscle function and gallbladder wall inflammation. $\mathcal{f}$ Hepatol 1994; 21 : 430-40.

20 Portincasa P, Di Ciaula A, Palmieri V, Baldassare G, Palasciano G. Enhancement of gallbladder emptying in gallstone patients after oral cholestyramine. Am $f$ Gastroenterol 1994; 89: 909-14.

21 Taha AS, Allison MC, Myara A, Trivin F, Duncan A, Russell RI. Does cholestyramine reduce the efficacy of ursodeoxycholic acid in primary biliary cirrhosis? European fournal of Gastroenterology and Hepatology 1994; 6: 535-8.

22 Bligh EG, Dyer WJ. A rapid method of total lipid extraction and purification. Can $\mathcal{F}$ Biochem Physiol 1959; 37: 911-7.

23 Turley SD, Dietschy JM. Reevaluation of the 3-hydroxysteroid dehydrogenase assay for total bile acids in bile. steroid dehydrogenase assay

24 Carey MC. Critical tables for calculating the cholesterol saturation of native bile. $\mathcal{F}$ Lipid Res 1978; 19: $945-55$.

25 Ruben ATh, vanBerge Henegouwen GP. A simple reverse phase high pressure liquid chromatographic determination of conjugated bile acids in serum and bile using a noval radial compression separation system. Clin Chim Acta 1982; 11: 941-50.

26 Heuman DM. Quantitative estimation of the hydrophylichydrophobic balance of mixed bile salt solutions. $\mathcal{F}$ Lipid Res 1989; 30: 719-30.

27 Everson GT, Braverman DZ, Johnson ML, Kern F Jr. A critical evaluation of real time ultrasonography for study of gallbladder volume and contraction. Gastroenterology of gallbladder volut

28 Stolk MFJ, Van Erpecum KJ, VanBerge-Henegouwen GP, Kesselring OFHW, Hopman WPM. Ultrasonography for Kesselring OFHW, Hopman WPM. Ultrasonography for the study of gallbladder volume and contraction: com-
parison of sum and cylinders method with ellipsoid and parison of sum and cylinders method with ellipsoid

29 Friedewald WT, Levy RJ. Estimation of the composition of low-density lipoprotein cholesterol in plasma, without use of preparative ultracentrifuge. Clin Chem 1972; 18: 499-592.

30 Armitage P, Berry G. Statistical methods in medical research. 2nd ed. Oxford: Blackwell Scientific, 1987: 296-357.

31 Horiuchi I, Toshihide O, Tazuma S, Mizuno T, Takizawa I, Kaijyama G. Effects of pravastatin (CS 514) on biliary lipid metabolism in patients with hyperlipidaemia. Metabolism 1991; 40: 226-30.

32 Reihner E, Rudling M, Stahlberg D, Berglund L, Ewerth S, Bjorkhem I, et al. Influence of pravastatin, a specific inhibitor of HMG-CoA reductase on hepatic metabolism of cholesterol. N Engl f Med 1990; 323: 224-8.

33 Tazuma $S$, Ohya $T$, Teramen $K$, Horikawa $K$, Yamashita $\mathrm{Y}, \mathrm{Ochi} \mathrm{H}$, et al. Effects of long-term treatment with low dose pravastatin, a competitive inhibitor of hydroxymethylglutaryl coenzyme A reductase, on biliary lipid metastasibility in patients with hypercholesterolaemia. Hepatology 1993; 18: 308A.

34 Cipolla A, Mazzella G, Villanova N, Montagnani M, Salzetta A, Festi D, et al. Effect of simvastatin and UDCA on biliary lipid secretion and CSI during weight reduction [Abstract]. Gastroenterology 1993; 104: A889.

35 Schwartz CC, Bergman M, Vlahcevic ZR, Halloran LG, Gregory DH, Swell L. Multicompartmental analysis of Gregory DH, Swell L. Multicompartmental analysis of cholesterol metabolism in man: characterization of the hepatic bile acid and biliary ch:

36 Bjorkhem I, Lewenhaupt A. Preferential utilization of newly synthesized cholesterol as substrate for bile acid diosynthesis. F Biol Chem 1979; 254: 5252-6.

37 Grundy SM, Ahrens Jr EH, Salen G. Interruption of the enterohepatic circulation in bile acids in man: comparative effects of cholestyramine and ileal exclusion on cholesterol metabolism. F Lab Clin Med 1971; 78: 94-121. 38 Davis RA, Highsmith WE, Malone McNeal M, 
Archambault Schexnayder J, Kuan JCW. Bile acid synthesis by cultured rat hepatocytes: inhibition by mevinolin but not by bile acids. $f$ Biol Chem 1983; 258: 4079-82.

39 Loria P, Bertolotti M, Cassinadri MT, Dilengite MA, Bozzoli M, Carubbi F, et al. Short term effects of simvastatin on bile acid synthesis and bile lipid secretion in human subjects. Hepatology 1994; 19: 882-8.

40 Muraca M, Baggio G, Miconi L, Vilei MT, Martini S, Gabelli $C$, et al Acute effects of HMG-CoA reductase inhibitors on biliary lipids in patients with interrupted enterohepatic circulation. Eur $\mathcal{f}$ Clin Invest 1991; 21: enter

41 Garbutt JT, Kenney TJ. Effect of cholestyramine on bile acid metabolism in normal man. $\mathcal{f}$ Clin Invest 1972; 51: acid metabolism in normal man. $\mathcal{F}$ Chn Invest 1972, S1:
$2781-9$. 42 Ekdahl PH, Sjövall J. On the conjugation and formation of
bile acids in the human liver. I. On the excretion of bile acids by patients with postoperative choledochostomy drainage. Acta Chir Scand 1958; 114: 439-52.
43 Stolk MFJ, van de Heijning BJM, van Erpecum KJ, van den Broek AMWC, Renooij W, van Berge Henegouwen GP. The effect of bile acid hydrophobicity on nucleation of several types of cholesterol crystals from model bile vesicles. F Hepatol 1994; 20: 802-10.

44 Garbutt JT, Heaton KW, Lack L, Tyor MP. Increased ratio of glycine to taurine conjugated bile salts in patients with ileal discorders. Gastroenterology 1969; 56: 711 .

45 Pentikainen PJ, Saraheimo M, Schwartz JI, Amin RD, Schwartz MS, Brunner F, et al. Comparative pharmacokinetics of lovastatin, simvastatin and pravastatin in humans. $\mathcal{F}$ Clin Pharmacol 1992; 32: 136-40.

46 Mauro VF. Clinical pharmacokinetics and practical applications of simvastatin. Clin Pharmacokinet 1993; 24: tions of 202 .

47 Palasciano G, Portincasa P, Belfiore H, Baldassare G; Albano $O$. Opposite effects of cholestyramine and loxiglumide on gallbladder dynamics in humans. Gastroenterology 1992; 102: 633-9. 